\title{
EARLY GROWTH PERFORMANCES OF THREE LEGUMES (ALBIZIA LEBBECK, LEUCAENA LEUCOCEPHALA AND PARKIA BIGLOBOSA) AND THEIR EFFECTS ON THE NITROGEN CONTENT OF THREE SOIL TYPES
}

\author{
KAREEM, I. A. ${ }^{1 *}$ AND ANIMASAUN, R. A. ${ }^{2}$ \\ *1,2,Department of Plant Science \& Biotechnology, Faculty of Science, Adekunle Ajasin University, Akungba Akoko, \\ Ondo State, Nigeria Email: driakareem@yahoo.com,driakareem19@gmail.com,ibraheem.kareem@aaua.edu.ng
}

*Corresponding Author: -

Email:driakareem@yahoo.com,driakareem19@gmail.com,ibraheem.kareem@aaua.edu.ng

\begin{abstract}
: -
The fact that numerous benefits are derivable from certain tree legumes especially in the sphere of nitrogen fixation, soil fertility improvement, land reclamation and fodder cannot be over emphasized. Thus, early growth studies on the morphological indices of three leguminous /nitrogen fixing trees (Albizia lebbeck, Leucacea leucocephala and Parkia biglobosa) as influenced by different soil types and variation in their nitrogen fixation potentials were investigated. It was a $3 \times 3$ factorial experiment in completely randomized design comprising 2 factors (soil types and tree species) each at three levels. Initial / pre-experimental soil analysis, seed sowing/planting in three soil types (river sand, clay, loam) tending operations (watering, thinning, weeding, insect control), data collection on seedling emergence (S.E.), morphological growth parameters (plant height, number of leaves/branches, collar, leaf area) for 12 weeks, post experimental soil analysis and data analysis were carried out. Results indicated that A. lebbeck and P. biglobosa seeds sown in river sand and clayey soil respectively had the fastest germination/ S.E. rate (10 days after planting) and the least were seeds planted in clayey soil. Outstanding performances were observed in L. leucocephala and A. lebbeck seedlings planted in loamy soil while P. biglobosa was the least in most of treatment combinations. Analysis of variance indicated significant differences (at $P \leq 0.05)$ among all the morphological growth characters. There were variations in percentage nitrogen $(\% N)$ fixed, soil analysis showed that A. lebbeck seedlings in river sand had the highest value $(6.29 \% N) \backslash$ and the least value $(1.45 \% \mathrm{~N})$ was observed in P. biglobosa (difference between initial and final soil analyses).
\end{abstract}

Keywords: Growth performance, tree legumes, nitrogen fixation, influence, soil types,

\section{(우 (\$) (1)}




\subsection{INTRODUCTION}

Soil fertility constraint has been identified as one of the major threats to food security in tropical Africa (IFDC, 1997) and an annual average loss has been put at $24 \mathrm{~kg}$ nutrient per hectare comprising $10 \mathrm{~kg} \mathrm{~N}, 4 \mathrm{~kg} \mathrm{P}_{2} \mathrm{O}_{5}$ and $10 \mathrm{~kg} \mathrm{~K} \mathrm{~K}_{2} \mathrm{O}$ (FAO, 2007). The term soil fertility refers to the capacity of the soil to support plants' growth on sustained basis and subsequently yielding quantities of expected products that are close to the known potential (Gachene and Kimaru, 2003) under certain environmental conditions. Nutrient status is maintained under natural ecosystem by the interactions between the soils and plant communities that depend on a high degree of recycling (Young, 1997c). Owing to the decrease in the fallow period arising from pressure on land, soil fertility decline is increasing at alarming rate. This necessitates urgent solution that can remedy this unpleasant situation which should not only be centered on inorganic/chemical fertilizer application. Topsoil organic matter had been drastically reduced due to intense cultivation /continuous cropping in most tropical soils and this organic matter had been a measure of the level of nutrient status (Adu, 1992). Also, the reduction in the quantity and quality of litter is not unconnected with the persistent annual wildfire/bush burning and action of termites (Kareem, 2017). Nitrogen content can be increased through application of green manure/animal wastes which will concomitantly improve the nutrient status. But the cost of procuring these organic manures that will be adequate for several hectares of farmland yearly has been a serious predicament.

Thus, a more reliable and sustainable means of augmenting and maintaining the soil nutrient status is the use of certain multipurpose tree species that are often employed in agro-forestry systems (Famuyide and Kareem, 2008; Kareem, 2017). This is because a good number of multipurpose tree species are mostly nitrogen fixing ones (by virtue of the rhizobial bacteria in their root nodules) coupled with their profuse litter deposition (especially during the dry season since most of them are deciduous). This litter undergoes rapid decomposition, mineralization and subsequently absorbed by crops most especially under alley cropping (Kareem, 2015). Besides their positive roles in the sphere of nitrogen fixation and litter augmentation, they ensure continuous sustainability of soils through erosion control and thereby paving way for good environmental conditions. Other benefits such as fodder/ forage, fence poles, fuel wood and stakes are obtainable from nitrogen fixing trees such as Albizia lebbeck, Leucacea leucocephala, Gliricidia sepium, Parkia biglobosa and Acacia auriculuforms. Shrubby legume like Cajanus cajan (pigeon pea) is perennial, nitrogen fixing, produces edible fruits and profuse litter and ditto to another tree legume named Parkia biglobosa which is in the family Leguminosae/Mimosideae commonly called locust bean tree (Hopkins, 1983). Subsequently, this study attempts to investigate the early growth and nitrogen fixing rates of three common leguminous trees (Albizia lebbeck, Leucaena leucocephala and Parkia biglobosa) so as to serve as reliable basis for subsequent recommendation for improvement of soil nutrient status, soil/land reclamation and production of other numerous products/benefits (forage/fodder, fuel wood, poles, beekeepinghoney production, stakes, locust bean, etc).

\subsection{Materials and Method}

This experiment was conducted in the field research site of the Plant Science and Biotechnology Department, Faculty of Science, Adekunle Ajasin University, Akungba Akoko, Ondo State, Nigeria (longitude $5^{0} 44^{1} €$, latitude $7^{0} 28^{1} \mathrm{~N}$ ). This study area is situated in the tropical rain forest vegetation in the western part of Nigeria. This area is adversely affected by annual bush burning, agricultural activities, deforestation and over grazing. The annual rainfall is between $15002000 \mathrm{~mm}$ while the average annual temperature is about $30^{\circ} \mathrm{c}$.

Some of the materials employed in carrying out the experiment were procured from the University premises (these include different soil types (washed river sand, clays soil, loamy soil, viable seeds of Albizia lebbeck, Leaucaena leucocephala and Parkia biglobosa) Medium sized polythene pots (finely perforated at the bottom to prevent water logging/flooding during watering) were sourced/purchased from a market in the University town (Akungba). The experimental design employed was a 3x3 factorial experiment in complete randomized design (consisting of two factors: soil types and tree species). The number of treatment combinations was nine (9) and each treatment combination had three (3) replicates. The experimental plot layout is as shown in Table 1 below:

Table 1: Experimental plot lay-out (3 replicates per treatment combination

\begin{tabular}{|c|c|c|c|}
\hline Tree Species & & Soil Types & \\
\hline$(3)$ & River Sand & Clayey Soil & Loamy Soil \\
\hline $\mathrm{b}_{1}$ & $\begin{array}{c}\mathrm{a}_{0} \\
\mathrm{a} 0 \mathrm{~b} 1-\mathrm{a} 0 \mathrm{~b} 1-\mathrm{a} 0 \mathrm{~b} 1\end{array}$ & $\frac{a_{1}}{a 1 b 1-a 1 b 1-a 1 b 1}$ & $\frac{a_{2}}{a 2 b 1-a 2 b 1-a 2 b 1}$ \\
\hline b2 & $a 0 b 2-a 0 b 2-a 0 b 2$ & a1b2-a1b2-a1b2 & $a 2 b 2-a 2 b 2-a 2 b 2$ \\
\hline b3 & $a 0 b 3-a 0 b 3-a 0 b 3$ & a1b3-a1b3-a1b3 & $a 2 b 3-a 2 b 3-a 2 b 3$ \\
\hline
\end{tabular}

Note: $\mathrm{a}_{0} \mathrm{~b}_{1}=$ Albizia lebbeck seeds planted in river sand.

$\mathrm{a}_{1} \mathrm{~b}_{1}=$ Albizia lebbeck seeds planted in clayey soil,

$\mathrm{a}_{2} \mathrm{~b}_{1}=$ Albizia lebbeck seeds planted in loamy soil

$\mathrm{a}_{0} \mathrm{~b}_{2}=$ Leucaeca leucocephala seeds plant in river sand

$\mathrm{a}_{1} \mathrm{~b}_{2}=$ Leucaeca leucocephala seeds planted in clayey soil

$\mathrm{a}_{2} \mathrm{~b}_{2}=$ Leucaeca leucocephala seeds planted in loamy soil

$\mathrm{a}_{\mathrm{o}} \mathrm{b}_{3}=$ Parkia biglobosa seeds planted in river sand

$\mathrm{a}_{1} \mathrm{~b}_{3}=$ Parkia biglobosa seeds planted in clayey soil

$\mathrm{a}_{2} \mathrm{~b}_{3}=$ Parkia biglobosa seeds planted in loamy soil 
The initial soil physicochemical analysis of the soil samples. This became imperative so as to know the nutrient status of the different soil samples especially the nitrogen content (total/\% $\mathrm{N}_{2}$ ) prior to the commencement of the experiment. The soil samples were analyzed by following laboratory standard procedures. The soil parameters (characteristics) considered were $\mathrm{pH}$, organic matter/organic carbon, total $/ \% \mathrm{~N}_{2}$, Available phosphorus, exchangeable bases $(\mathrm{K}, \mathrm{Ca}, \mathrm{Mg}$, $\mathrm{Ca}, \mathrm{Cu}, \mathrm{Na}$ ), exchangeable acidity, effective cation exchange capacity, \% sand/clay/silt and textural class. The post experimental soil analysis was also carried out in order to assess the variation between the initial and final percentage nitrogen content.

The actual planting procedure and tending operations: Sequel to the setting-up of the experiment (arrangement of the polythene pots in line with the experimental design as shown in Table 1 above) each of the nine (9) treatment combinations was replicated three (3) times. The polythene pots had earlier been perforated at the base (bottom) to prevent water logging during watering. The polythene pots were then filled with the different soil samples/types (river sand, loamy and clayey soils) and watered immediately to ensure good soil condition. The seeds (without pre-germination treatment) of the different species were planted (between 6:00 and 6:30pm in the evening). In order to pave way for effective growth and development under healthy/good environmental conditions, some tending operations such as watering, weeding and insect control were carried out.

\section{Data Collection and Statistical Analysis}

Relevant/necessary data were collected on the following morphological growth indices: Plant height was taken by measuring the vertical distance from the base (soil level) to the terminal bud by means of a meter rule at two (2) weeks interval commencing from the $4^{\text {th }}$ week to the $12^{\text {th }}$ week. The stem collar girth of the seedlings from the nine (9) treatment combinations was taken with a venier caliper ( $2 \mathrm{~cm}$ from soil level), number of leaves was obtained by physical counting, leaf area was taken by random selection of three (3) leaves per plant (smallest, medium and largest) followed by calculating the area of each of the three categories of leaves (by multiplying the mean/average of three widths on each leaf by the length), then the value obtained was multiplied by the total number of leaves per plant/seedling. The number of branches was gotten by counting (physically/manually) per seedling (in all the treatment combinations). The data collected were subjected to analysis of variance (ANOVA) technique so as to find out if there were significant differences among the nine treatment combinations. The least significant difference (LSD) techniques were employed where significant differences were observed.

\subsection{Results \\ The initial soil properties}

The results from the soil analyses were as shown in Table 2 below. The pre-planting soil analysis indicated the following results: the $\mathrm{pH}$ ranged between 5.71 and 6.22 , river sand $\left(\mathrm{a}_{0}\right)$ had the highest $\mathrm{pH}$ of 6.22 and this was followed by loamy soil $\left(a_{2}\right)$ with a $\mathrm{pH}$ of 6.1 while clayey $\left(\mathrm{a}_{1}\right)$ soil has the lowest $\mathrm{pH}$ of 5.71 . The organic carbon obtained from the analysis ranged from $14.71-42.60 \%$. Loamy soil $\left(\mathrm{a}_{1}\right)$ had the highest percentage organic carbon $(42.60 \%)$ followed by river sand $(16.34 \%)$ while clayey soil $\left(\mathrm{a}_{1}\right)$ had the lowest percentage organic carbon $(14.71 \%)$. The total Nitrogen ranged from 1.83 $-5.2 \%$ and as observed, clayey soil had the highest percentage / total nitrogen $(5.2 \%)$ followed by loamy soil (4.35\%) and the soil type with the lowest percentage/total nitrogen was river sand $(1.83 \%)$. The available phosphorous ranged between 22.34 and $36.67 \mathrm{ppm}$. Loam had the highest content of available phosphorous (36.67ppm) followed by clayey soil with $(26.73 \mathrm{ppm})$ and river sand had the lowest content of available phosphorous (22.34ppm). The potassium (K) from the analysis ranged from $0.26-0.41 \mathrm{c}-\mathrm{mol}(+) \mathrm{kg}_{-}{ }^{1}$, loamy soil had the highest $\mathrm{K}$ content of $0.41 \mathrm{c}-\mathrm{mol}^{(+)} \mathrm{kg}-{ }^{1}$, followed by clayey soil [with $0.32 \mathrm{c}-\mathrm{mol}(+) \mathrm{kg}-^{1}$ ] while river sand had the lowest $\mathrm{K}$ content of $0.26 \mathrm{c}-\mathrm{mol}_{(+)} \mathrm{kg}_{-}{ }^{1}$.

The calcium content ranged from between $0.22-0.29 \mathrm{mg} / \mathrm{kg}$. It was observed that loamy $\left(\mathrm{a}_{2}\right)$ had the highest calcium content of $\left(0.29 \mathrm{mg} / \mathrm{kg}\right.$, followed by clayey soil $\left(\mathrm{a}_{1}\right)$ with $(0.24 \mathrm{mg} / \mathrm{kg})$ and the lowest soil type was river sand $\left(\mathrm{a}_{0}\right)$ with $0.22 \mathrm{mg} / \mathrm{kg}$. The magnesium ranged between $0.5 \mathrm{c}-\mathrm{mol}(+) \mathrm{kg}^{-1}$ and $2.16 \mathrm{cmol}$. It was loamy soil $\left(\mathrm{a}_{2}\right)$ that had the highest value of $2.16 \mathrm{c}-\mathrm{mol}(+) \mathrm{kg}^{-1}$ followed by clayey soil $\left(\mathrm{a}_{1}\right)$ with $1.19 \mathrm{cmol}(+) \mathrm{kg}^{-1}$ and river sand $\left(\mathrm{a}_{0}\right)$ had the lowest magnesium content of $0.5 \mathrm{cmol}(+) \mathrm{kg}^{-1}$. The cupper content from the analyzed soil ranged between $3.43 \mathrm{cmol}^{(+)} \mathrm{kg}^{-1}$ and $7.20 \mathrm{cmol}(+) \mathrm{kg}^{-1}$. Loamy soil $\left(\mathrm{a}_{2}\right)$ had the highest copper content of $7.20 \mathrm{cmol}(+) \mathrm{kg}^{-1}$, followed by clayey soil $\left(\mathrm{a}_{1}\right)$ with $6.12 \mathrm{cmol}(+) \mathrm{kg}^{-1}$, and river sand $\left(\mathrm{a}_{0}\right)$ had the lowest copper content of $3.43 \mathrm{cmol}(+) \mathrm{kg}^{-1}$. The content of sodium from the analyzed soil types range between $0.26 \mathrm{cmol}(+) \mathrm{kg}^{-1}$, and $0.52(+) \mathrm{kg}^{-1}$, loamy soil $\left(\mathrm{a}_{2}\right)$ had the highest value of $0.52 \mathrm{cmol}(+) \mathrm{kg}^{-1}$, followed by $\left(\mathrm{a}_{1}\right)$ clayey soil with value of $0.43 \mathrm{cmol}(+) \mathrm{kg}^{-1}$, and $\left(\mathrm{a}_{0}\right)$ had the least value of 0.26 cmol $(+) \mathrm{kg}^{-1}$. The highest value of exchangeable acidity $\left[0.79 \mathrm{cmol}(+) \mathrm{kg}^{-1}\right]$ was observed in $\mathrm{a}_{2}$, followed by a with 0.48 $\mathrm{cmol}(+) \mathrm{kg}^{-1}$ and $\mathrm{a}_{1}$ had the least value was $0.38 \mathrm{cmol}(+) \mathrm{kg}^{-1}$. The effective cation exchangeable capacity (ECEC) ranged between $5.15 \mathrm{cmol}(+) \mathrm{kg}^{-1}$ and $11.37 \mathrm{cmol}(+) \mathrm{kg}^{-1}, \mathrm{a}_{2}$ had the highest ECEC of $11.37 \mathrm{cmol}^{(+)} \mathrm{kg}^{-1}$, followed by a with $8.68 \mathrm{cmol}(+) \mathrm{kg}^{-1}$ and $\mathrm{a}_{0}$ had the lowest value of $5.15 \mathrm{cmol}(+) \mathrm{kg}^{-1}$. 
Table 2 Initial soil physicochemical properties analysis of the soil types

\begin{tabular}{|l|l|l|l|}
\hline Soil parameters & River sand & Clayey & Loamy \\
\hline $\mathrm{pH}\left(\mathrm{H}_{2} \mathrm{O}\right)$ & 6.22 & 5.71 & 6.1 \\
\hline Organic matter \% & 16.34 & 14.71 & 42.6 \\
\hline Total nitrogen \% & 1.83 & 5.2 & 4.35 \\
\hline Av. P ppm & 22.34 & 26.73 & 36.67 \\
\hline $\mathrm{K} \mathrm{cmol}(+) \mathrm{kg}^{-1}$ & 0.26 & 0.32 & 0.41 \\
\hline $\mathrm{Ca} \mathrm{mg} / \mathrm{kg}^{\mathrm{Mg} \mathrm{cmol}(+) \mathrm{kg}^{-1}}$ & 0.22 & 0.24 & 0.29 \\
\hline $\mathrm{Cu} \mathrm{cmol}(+) \mathrm{kg}^{-1}$ & 0.5 & 1.19 & 2.16 \\
\hline $\mathrm{Na} \mathrm{cmol}(+) \mathrm{kg}^{-1}$ & 3.43 & 6.12 & 7.20 \\
\hline EA cmol $(+) \mathrm{kg}^{-1}$ & 0.48 & 0.43 & 0.52 \\
\hline ECEC cmol $(+) \mathrm{kg}^{-1}$ & 5.15 & 0.38 & 0.79 \\
\hline Sandy & $75.00 \%$ & 8.68 & 11.37 \\
\hline Clay & $8.50 \%$ & 32.80 & 61.80 \\
\hline Slit & $16.50 \%$ & $51.20 \%$ & $20.20 \%$ \\
\hline Textural class & River sand & $16.00 \%$ & $18.00 \%$ \\
\hline
\end{tabular}

Av. P: Available phosphorous, E.A.: Exchangeable acidity, ECEC: Effective cation exchange capacity.

Germination / Seedling Emergence: The three leguminous plants varied in days to seedling emergence. The variation was between 10 and 16 days after planting. A. labbeck seed sown river sand $\left(\mathrm{a}_{0} \mathrm{~b}_{1}\right)$ and that of P.biglobosa planted in clayey soil $\left(\mathrm{a}_{1} \mathrm{~b}_{3}\right)$ emerged (first) at the $10^{\text {th }}$ day after planting (DAP). These were followed by L. leucocephala seed sown in river sand $\left(a_{0} b_{2}\right)$ and $L$. leucocephala seed sown in loam $\left(a_{2} b_{2}\right)$ which emerged on the $11^{\text {th }}$ DAP. Other treatment combinations (TC) such as $a_{2} b_{1}$ and $a_{2} b_{3}$ emerged 13 DAP, $a_{0} b_{3}$ was 14 DAP, $a_{1} b_{2}$ at 15 DAP and alb1 was the last to emerge at 16 DAP (check Table1for the acronyms). With regard to plant height (Table 3), it was $a_{2} b_{2}$ that had the highest value $(1474 \mathrm{~cm})$ and aob3 was the least $(4.88 \mathrm{~cm}$, Table 4 below). The trend was a bit different in number of leaves, $L$. leucocephala in loam had the highest value followed by A. lebbeck in river sand and least was P.biglobosa in clayey soil (Table 5 below). L. leucocephala in loam recorded the highest value in stem collar girth, the next was A. lebbeck in river sand and L. leucocephala in clayey soil had lowest value (Table 5 below). The result obtained in number of branches was almost the same like that of the collar girth except that $A$. lebbeck in clayey had the least value (Table 6 below). $L$. leucocephala seedlings planted in loamy soil had highest value in leaf area followed by A. lebbeck and L. leucocephala seedlings planted in clayey soil was the least (Table 7 below). Analysis of variance indicated significant differences (at $\mathrm{P} \leq 0.05$ ) among all the morphological growth characters (Tables 3 - 7 below) at the $12^{\text {th }}$ week after germination / seedling emergence.

Table 3: Extract from statistical analysis on plant height $(\mathrm{cm})$ under different treatment combinations (4 - 12 weeks) with mean, standard error and LSD

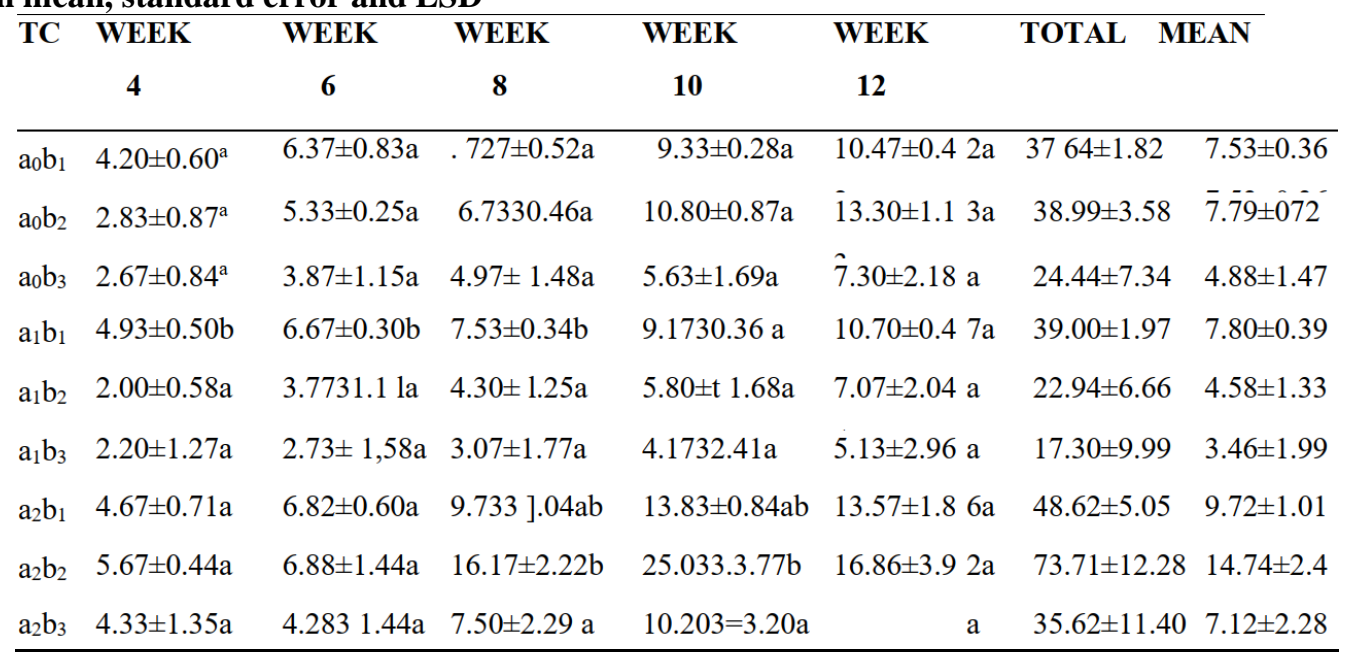

Note: Treatment combination, $\mathrm{a}_{0}=$ river sand, $\mathrm{a}_{1}=$ clayey soil. a8.31 ${ }_{2}=$ loamy soil, $\mathrm{b} \pm 2.85{ }_{1}=$ Albizia lebbeck, $\mathrm{b}_{2}=$ Leucaena leucocephala, $\mathrm{b}_{3}=$ Parkia biglobosa. Values with different alphabets as superscript were significantly $(\mathrm{P} \leq 0.05)$ different and those that had the same alphabets as superscript were different but not significantly different. 
Table 4: Extract from statistical analysis on number of leaves in treatment combinations (4 - 12 weeks) showing mean, standard error and LSD

\begin{tabular}{|c|c|c|c|c|c|c|}
\hline TC & WEEK 4 WEEK 6 & WEEK 8 & WEEK 10 & WEEK 12 & TOTAL & MEAN \\
\hline $\mathrm{a}_{0} \mathrm{~b}_{1}$ & $5.33 \pm 0.5110 .0 \pm 1.0\left(>^{\mathrm{a}}\right.$ & $13.67 \pm 0.77^{\mathrm{a}}$ & $17.67 \pm 0.84^{\mathrm{a}}$ & $23.33 \pm 0.69^{\mathrm{a}}$ & $69.33 \pm 3.81$ & $13.87 \mathrm{iO} 76$ \\
\hline $\mathrm{a}_{0} \mathrm{~b}_{2}$ & $3.67 \pm 0.19 \cdot 8.00 \pm 0.58^{\prime \prime}$ & $14.33 \pm 1.89^{\mathrm{a}}$ & $24.67 \pm 3.67^{\mathrm{a}}$ & $39.33 \pm 4.97^{b}$ & $90.00 \pm 11.3$ & $18.00 \pm:, 26$ \\
\hline$a_{0} b_{3}$ & $3.67 \pm 1.079 .67 \pm 3.02^{\mathrm{a}}$ & $10.67 \pm 3.15^{\mathrm{a}}$ & $15.00 \pm 4.33^{\mathrm{a}}$ & $21.0 \pm 6.12$ & $60.0 \mathrm{U} 17.69$ & $12.00 \mathrm{a} 2.26$ \\
\hline$a_{1} b_{1}$ & $7.33 \pm 0.5112 .67 \pm 0.69^{a}$ & $17.33 \pm 0.38^{\mathrm{a}}$ & $21.33 \pm 0.19^{\mathrm{b}}$ & $27.67 \pm 1.35^{\mathrm{a}}$ & $86.33 \pm 3.12$ & $17.27 \pm 0.62$ \\
\hline $\mathrm{a}_{1} \mathrm{~b}_{2}$ & $2.33 \pm 2.085 .67 \pm 1.64^{1}$ & $8.33 \pm 2.41^{\mathrm{a}}$ & $18.67 \pm 5.43^{\mathrm{ab}}$ & $23.67 \pm 6.83^{\mathrm{a}}$ & $58.67 \pm 18.39$ & $11.73 \pm 3.68$ \\
\hline$a_{1} b_{3}$ & $3.00 \pm 1.736 .00 \pm 3.46^{\mathrm{a}}$ & $8.33 \pm 4.81^{\mathrm{a}}$ & $9.67 \pm 5.58^{\mathrm{a}}$ & $13.33 \pm 7.69^{\mathrm{a}}$ & $40.33 \pm 23.27$ & $8.06 \mathrm{i} 466$ \\
\hline $\mathrm{a}_{2} \mathrm{~b}_{1}$ & $4.67 \pm 0.3811 .0011 .33^{a}$ & $15.33 \pm 1.07^{\mathrm{a}}$ & $24.67 \pm 0.84^{\mathrm{a}}$ & $31.67 \pm 0.51^{\mathrm{a}}$ & $87.34 \pm 4.13$ & $17.47 \mathrm{i} 0.83$ \\
\hline $\mathrm{a}_{2} \mathrm{~b}_{2}$ & $5.33 \pm 0.5122 .0 \pm 3.84^{\mathrm{h}}$ & $39.00 \pm 5.00^{\mathrm{b}}$ & $51.33 \pm 7.03^{b}$ & $67.67 \pm 8.70^{\mathrm{b}}$ & $185.33 \pm 25.0$ & $37.06 \mathrm{i} 5.02$ \\
\hline $\mathrm{a}_{2} \mathrm{~b}_{3}$ & $5.33 \pm 1.54 \quad 15.22 \pm 3.33^{\mathrm{ab}}$ & $16.33 \pm 4.8^{\mathrm{a}}$ & $22.00 \pm 6.56^{\mathrm{a}}$ & $30.0 \pm 8.72^{\mathrm{a}}$ & $\hat{88} .88 \pm 24.95$ & 17.78. 4.99 \\
\hline
\end{tabular}

Note: Treatment combination, $\mathrm{a}_{0}=$ river sand, $\mathrm{a} 1=$ clayey soil. $\mathrm{b} 2=$ Albizia lebbeck, $\mathrm{b} 2=$ Leucaena leucocephala, $\mathrm{b}_{3}=$ Parkia biglosa. Values with different alphabets as superscript are significantly $(\mathrm{P} \leq 0.05)$ different and those with the same alphabets as superscript were different but not significantly different.

Table 5: Extract from statistical analysis on collar girth (cm) under different treatment combinations (4 - 12 weeks) with mean, standard error and LSD

\begin{tabular}{|c|c|c|c|c|}
\hline TC & WEEK 4 WEEK 6 & WEEK 8 & WEEK 10 WEEK 12 TOTAL & MEAN \\
\hline $\mathrm{a}_{0} \mathrm{~b}_{1}$ & $0.30 \pm 0.03^{\mathrm{a}} 0.41 \pm 0.00$ & $1.20 \pm 0.03^{\mathrm{a}}$ & ${ }^{\mathrm{a}} 1.80 \pm 0.15^{\mathrm{a}} 2.10 \pm 0.15^{\mathrm{a}} 5.8140 .36$ & 1.1640 .77 \\
\hline $\mathrm{a}_{0} \mathrm{~b}_{2}$ & $0.23 \pm 0.04: \begin{array}{l}0.31 \pm 0.00 \\
6^{\mathrm{a}}\end{array}$ & $1.10 \pm 0.08^{\circ}$ & ${ }^{\mathrm{a}} 1.60 \mathrm{t}() .09^{\mathrm{a}} 1,97 \pm 0.08^{\mathrm{a}} 5.2140 .29$ & 1.0440 .05 \\
\hline $\mathrm{aob}_{3}$ & $0.10 \pm 0.03^{\mathrm{I}} 0.23 \pm 0.08^{\mathrm{a}}$ & $0.67 \pm 0.20^{2}$ & ${ }^{\mathrm{a}} 1.00 \pm 0.29^{\mathrm{a}} 1.30 \pm 0.38^{\mathrm{a}} 3.340 .98$ & 0.6640 .19 \\
\hline$a_{1} b_{1}$ & $0.27 \pm 0.02^{\mathrm{a}} 0.3740 .19^{\mathrm{a}}$ & $1.17 \pm 0.08^{\mathrm{b}}$ & ${ }^{b} 1.67$ t0.07 $1.9340 .13^{\mathrm{b}} 5.4140 .49$ & 1.0840 .09 \\
\hline$a_{1} b_{2}$ & $0.20 \pm 0.07^{\ddagger} 0.27 \pm 0.08^{\mathrm{a}}$ & $0.73 \pm 0.21^{a}$ & $1.17 \pm 0.34^{\mathrm{a}}{ }_{\mathrm{b}}^{1.2740 .37^{\mathrm{a}}} 36441.07$ & 0.7240 .21 \\
\hline$a_{1} b_{3}$ & $0.17 \pm 0.09^{\mathrm{a}} 0.13 \pm 0.08$ & $0.50 \pm 0.29^{2}$ & ${ }^{\mathrm{a}} 0.90 \pm 0.52^{\mathrm{a}} 0.7741 .44^{\mathrm{a}} 2.4742 .42$ & 0.4940 .48 \\
\hline $\mathrm{a}_{2} \mathrm{~b}_{1}$ & $0.33 \pm 0.04^{\mathrm{a}} 0.44 \pm 0.02^{\mathrm{a}}$ & $1.33 \pm 0.08^{2}$ & ${ }_{\mathrm{b}}^{2.0740 .10^{\mathrm{a}} 2.4340 .04^{\mathrm{a}}} 6.640 .28$ & 1.3240 .06 \\
\hline $\mathrm{a}_{2} \mathrm{~b}_{2}$ & $0.23 \pm 0.04^{1} 0.53 \pm 0.02^{\mathrm{a}}$ & $1.73 \pm 0.02^{2}$ & a 2.70 t0.03 $3.0340 .07^{b} 8.2240 .18$ & 1.6440 .04 \\
\hline$a_{2} b_{2}$ & $0.23 \pm 0.08: 0.33 \pm 0.10^{\mathrm{a}}$ & $1.13 \pm 0.33^{\circ}$ & ${ }^{\mathrm{a}} 1.7041 .49^{\mathrm{a}} 1.9340 .56^{3} 5.3242 .56$ & 1.0640 .51 \\
\hline
\end{tabular}

Note: Treatment combination. $\mathrm{a}_{0}=$ river sand. $\mathrm{a}_{1}=$ clayey soil. $\mathrm{a}_{2}=$ loamy soil. $\mathrm{b}_{1}=$ Alhizia lebbeck. $\mathrm{b}_{2=}$ Leucaena leucocephala, $\mathrm{b}_{3}=$ Parkia biglobosa. Values with different alphabets as superscript are significantly $(\mathrm{P} \leq 0.05)$ different while those that had the same alphabets as superscript were different but not at significant level. 
Table 6: Extract from statistical analysis on number of branches under different treatment combinations (4 - 12 weeks) with mean, standard error and LSD

\begin{tabular}{|c|c|c|c|c|c|c|c|}
\hline TC & WEEK 4 & WEEK 6 & WEEK 8 & WEEK 10 & WEEK 12 & TOTAL & MEAN \\
\hline & & & \multicolumn{5}{|c|}{$10.00 \pm 0.33^{\mathrm{a}}$} \\
\hline$a_{0} b_{1}$ & $2.67 \pm 0.19^{\mathrm{a}}$ & $4.67 \pm 0.51^{\mathrm{a}}$ & $6.00 \pm 0.33^{\mathrm{ab}}$ & ${ }^{b} 8.00 \pm 0.33^{\mathrm{ab}}$ & & $31.34 \pm 1.67$ & $6.27 \pm 0.33$ \\
\hline$a_{0} b_{2}$ & $3.00 \pm 0.33^{\mathrm{a}}$ & $5.00 \pm 0.00^{\mathrm{a}}$ & $7.67 \pm 0.51^{b}$ & $b_{b}^{10.67 \pm 0.51}$ & $14.33 \pm 0.19$ & $40.67 \pm 1.54$ & $48.13 \pm 0.31$ \\
\hline$a_{0} b_{3}$ & $1.67 \pm 0.51^{\mathrm{a}}$ & $3.00 \pm 0.88^{\mathrm{a}}$ & $4.00 \pm 1.15^{\circ}$ & $5.67 \pm 1.64^{a}$ & $6.33 \pm 5.51^{\mathrm{a}}$ & $20.67 \pm 9.69$ & $4.13 \pm 1.94$ \\
\hline$a_{1} b_{1}$ & $3.00 \pm 0.67^{b}$ & $6.67 \pm 0.38^{b}$ & $9.00 \pm 0.33^{b}$ & $\begin{array}{l}10.67 \\
0.38^{\mathrm{b}}\end{array}$ & $\pm_{b}^{11.33} \pm 0.19$ & $40.67 \pm 1.95$ & $8.13 \pm 0.39$ \\
\hline$a_{1} b_{2}$ & $1.33 \pm 0.38^{\mathrm{a}}$ & $3.00 \pm 0.88^{\mathrm{a}}$ & $\begin{array}{l}4.67 \\
1.39^{\mathrm{b}}\end{array}$ & ${ }^{ \pm} 6.33 \pm 1.84^{\mathrm{ab}}$ & $8.67 \pm 2.59^{\mathrm{ab}}$ & $24.00 \pm 7.08$ & $4.8 \pm 1.42$ \\
\hline$a_{1} b_{3}$ & $1.67 \pm 0.96^{\mathrm{ab}}$ & $2.33 \pm 1.35^{\mathrm{a}}$ & $1.00 \pm 0.58$ & $4.00 \pm 2.31^{\mathrm{a}}$ & $4.00 \pm 2.31^{\mathrm{a}}$ & $13.00 \pm 7.51$ & $2.6 \pm 1.50$ \\
\hline$a_{2} b_{1}$ & $3.33 \pm 0.38^{\mathrm{a}}$ & $6.00 \pm 0.58^{\mathrm{b}}$ & $9.00 \pm 0.67^{\mathrm{b}}$ & ${ }^{b} 11.67 \pm 0.58^{a}$ & $14.33 \pm 0.77^{\circ}$ & $44.33 \pm 2.98$ & $8.86 \pm 0.59$ \\
\hline$a_{2} b_{2}$ & $3.67 \pm 0.19^{\mathrm{a}}$ & $5.50 \pm 1.07^{\mathrm{a}}$ & $\underset{b}{a} 13.00 \pm 1.20$ & ${ }_{b}^{18.33 \pm 2.17}$ & ${ }_{b}^{20.33 \pm 1.68}$ & $60.83 \pm 6.31$ & $12.17 \pm 1.26$ \\
\hline$a_{2} b_{3}$ & $2.33 \pm 0.69^{\mathrm{a}}$ & $3.33 \pm 1.12^{\mathrm{a}}$ & $6.00 \pm 1.76^{a}$ & $8.33 \pm 2.41^{\mathrm{a}}$ & $8.72 \pm 2.91^{\mathrm{a}}$ & $28.71 \pm 8.89$ & $95.74 \pm 1.78$ \\
\hline
\end{tabular}

Note: Treatment combination. $\mathrm{a}_{0}=$ river sand. $\mathrm{a}_{1}=$ clayey soil. $\mathrm{a}_{2}=$ loamy soil. $\mathrm{b}_{1}=$ Alhizia lebbeck. $\mathrm{b}_{2}=$ Leucaena leucocephala, $\mathrm{b}_{3}=$ Parkia biglobosa . Values with different alphabets as superscript are significantly $(\mathrm{P} \leq 0.05)$ different while those with the same alphabets as superscript were different but not at significant level.

Table 7: Extract from statistical analysis on leaf area $\left(\mathrm{cm}^{2}\right)$ under different treatment combinations (4 - 12 weeks) with mean, standard error and LSD

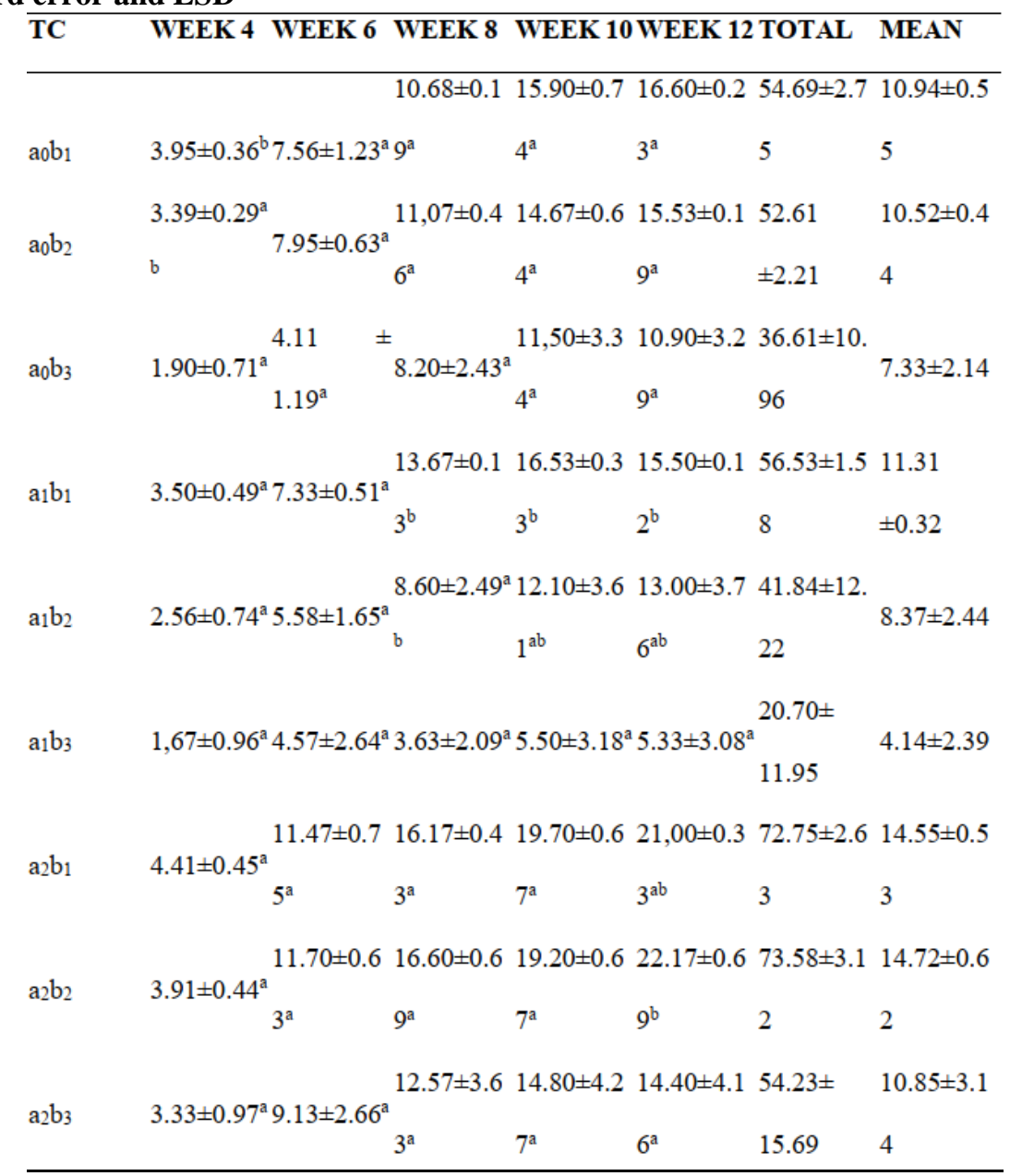

Note: Treatment combination, $\mathrm{a}_{0}=$ river sand, $\mathrm{a}_{1}=$ clayey soil. $\mathrm{a}_{2}=$ loamy soil $\mathrm{b}_{1}=$ Albizia lebbeck, $\mathrm{b}_{2}=$ Leucaena leucocephala, $\mathrm{b}_{3}=$ Parkia biglobosa. Values with different alphabets as superscript are significantly $(\mathrm{P} \leq 0.05)$ different 
while those with the same alphabets as superscripts were different but not significantly different. Post soil sample analysis on the percentage / total nitrogen

At the end of the experiment, soil samples from different treatment combinations were subjected to analysis to determine the differences (between initial and final )in percentage nitrogen fixed (Table 8: below)

Table 8: Variation in nitrogen content $(\%)$ of the initial and post experimental soil analyses

\begin{tabular}{lrrr} 
TC & Initial & \multicolumn{1}{l}{ Final } & Difference \\
\hline $\mathrm{a}_{0} \mathrm{~b}_{1}$ & 1.83 & 8.12 & 6.29 \\
$\mathrm{a}_{0} \mathrm{~b}_{2}$ & 1.83 & 7.49 & 5.66 \\
$\mathrm{a}_{0} \mathrm{~b}_{3}$ & 1.83 & 6.72 & 4.89 \\
$\mathrm{a}_{1} \mathrm{~b}_{1}$ & 5.20 & 8.61 & 3.41 \\
$\mathrm{a}_{1} \mathrm{~b}_{2}$ & 5.20 & 7.42 & 2.22 \\
$\mathrm{a}_{1} \mathrm{~b}_{3}$ & 5.20 & 6.65 & 1.45 \\
$\mathrm{a}_{2} \mathrm{~b}_{1}$ & 4.35 & 6.65 & 2.30 \\
$\mathrm{a}_{2} \mathrm{~b}_{2}$ & 4.35 & 6.62 & 2.27 \\
$\mathrm{a}_{2} \mathrm{~b}_{3}$ & 4.35 & 7.42 & 3.07 \\
\hline
\end{tabular}

Albizia lebbeck fixed the highest percentage nitrogen in all the soil types (which were $6.29 \%$ in $\mathrm{TC} \mathrm{a}_{0} \mathrm{~b}_{1}, 3.41 \%$ in $\mathrm{TC}$ $\mathrm{a}_{1} \mathrm{~b}_{1}$ ) except loamy soil where Parkia biglobosa had the highest value (3.07\%) in terms of difference between initial and final values. The next in rank was Leucaena leucocephala with $5.66 \%$ in TC $\mathrm{a}_{0} \mathrm{~b}_{2}, 2.22 \%$ in TC $\mathrm{a}_{1} \mathrm{~b}_{2}$ but Parkia biglobosa had the highest rate of nitrogen fixation in loamy soil $(3.07 \%$ : which was the difference between the values of the pre I post experimental soil analyses).

\subsection{Discussion}

The fact that it was at the $10^{\text {th }}$ day before observing seed germination /seedling emergence $\left(a_{0} b_{1} \& a_{1} b_{3}\right)$ and it took 16 days for the last to emerge indicated that all the seeds of leguminous tree exhibited dormancy at various levels since none was given pre-germination treatment prior to sowing (Kareem et. al., 2001). Also, the variations in days to seedling emergence could have been as a result of disparities in the characteristics of the soil types in terms of their paucity (particle size), porosity, density, water retaining / holding capacity and chemical properties. The difference in plant height among the three legumes [Albizia lebbeck $\left(\mathrm{b}_{1}\right)$, Leucaena leucocephala $\left(\mathrm{b}_{2}\right)$ and Parkia biglobosa $\left(\mathrm{b}_{3}\right)$ ] under different growth media was probably due to variation in the nutrient status of the growth media. For instance, loamy soil had the highest plant height owing to its high nutrient status as revealed by the physicochemical analysis of the soil samples. Also, the two species that grew faster $\left(A\right.$. lebbeck $\left(\mathrm{b}_{1}\right)$, L. leucocephala) are known to exhibit fast growth rate on a wide range of soils including those that are alkaline and saline but cannot thrive well in water logged condition ((Prinsen, 1986; Lowry et. al., 1992; Kareem, 2005) as opposed to P. biglobosa which was the lowest (in growth rate). The same reasons were possibly responsible for the variations in other morphological growth indices such as number of leaves / branches, collar girth and leaf area (in terms of differential nutrient statuses of the various growth media especially organic matter, nitrogen, available phosphorus and the exchangeable bases) which are essential for proper growth (Kareem et. al., 2015). Other contributory factors could be level of root development (i. e. extensiveness) and corresponding rates of absorption of nutrients of the different tree legumes.

Variation in nitrogen fixation of all the three leguminous trees could be attributed to the fact that A. lebbeck had been known as renowned soil improver (inherent quality) because of its profuse nodulation (Kadiata, et. al., 1996). It has also been observed that Leucaena leucocephala is an active nitrogen fixer (Bhati and Kapoor,1984) and reports have shown that it can fix $98-134 \mathrm{~kg} \mathrm{~N}_{2}$ ha-' in 6 months (for fully grown tree) and the high nitrogen fixing potential of this tree is related to its abundant nodulation under specific soil conditions. The nodule dry weight was reported to reach approximately $51 \mathrm{~kg} \mathrm{ha-}{ }^{1}$ in a stand of 830 trees ha- ${ }^{1}$ (Hogberg and Kvarnstorm. 1982) and approximately $63 \mathrm{~kg}$ ha- ${ }^{1}$ in a stand of 2500 trees ha- $^{-1}$ (Lulandala and Hall, 1986) Therefore, any of the trees could be employed to improve nitrogen content in the soil but Albizia lebbeck and Leucaena leucocephala could be given priority in soil conservation/land reclamation and agro-forestry systems (especially alley cropping).

\subsection{Conclusion and Recommendations}

Based on the results obtained, it could be inferred that loamy soil is the most suitable soil for raising/producing the seedlings of the three nitrogen fixing trees (Albizia lebbeck, Leucaena leucocephala and Parkia biglobosa) sequel to the fact that it outstandingly promoted their growth rates. Similarly river sand could also be employed for the propagation of the trees as it was next to loamy soil in growth rate. In terms of nitrogen fixation, Albizia lebbeck could be used for rapid improvement of soil nutrient status seconded by Leucaena leucocephala then Parkia biglobosa. Farmers are advised to use natural means of improving soil fertility by planting nitrogen fixing trees since they also produce litter profusely because they are all deciduous tree species. More experiments could be conducted on production/propagation and nitrogen fixation potentials of all the three trees species due to their immense importance. 


\subsection{REFERENCES}

[1].Adu, S. V. (1992) Soils of the Kumasi Region, Ashanti Region Ghana Memoir 8: 77-90 Bhatia. N. and P. Kapoor (1984). Neigbour interaction between Leucaena leucocephala and Acacia nilotica in mixed plantations in Punjab.Leucaena Research Reports 5:18

[2].Bonkougou.E. G.. Djimde M, Ayuk ET, Zougrana I. Tchoundjeu Z. 1999. The market potential of parkland trees: Agroforestry Today. 11(1-2): 13-15.

[3].Famuyide, O. O. and Kareem, I. A. 2006. The Role of Forestry and Agro-forestry Activities in Environmental Sustainability.The Savanna : A Journal of the Environmental and Social Sciences. Vol.21 (Nos.1 \& 2 June \& Dec.) : $31-40$

[4].FAO, 2007. Environmental Protection of Natural Resources Management and Sustainable Development. Food and Agriculture Sector Development Policy on Food.(FASDEP II). Ministry of Food and Agriculture, Accra, Ghana. pp. $1-7$

[5].Gachene, C. K. K. and Kimaru, K. 2003. Soil fertility and land productivity. A guide for extention workers in the eastern Africa region. Regional Land Management Unit, RELMA/ Sida. ICRAF House, Gigiri, P. O. Box 63403, Nairobi 00619, Kenya.

[6].Hogberg, P. and M. kvarnshom., 1982. Nitrogen fixation by woody legumes. Leucaena leucocephala. Plant soil 66:218.

[7].Hopkins, H. C.1983. The taxonomy, reproductive biology and economic potential of Parkia biglobosa (Leguminosae: Mimosideae) in Africa and Madagascar. Botanical Journal of the Linnean Society 87:135-167.

[8].IFDC, 1997. Framework for National Soil Fertility Improvement Action Plans. World Bank, Washington D. C., 10pp.

[9].Kadiata, B. D.; Mulongoy,K.andIsirimahN.O.(1996).TimeCourse of Biological Nitrogen Fixation, Nitrogen Absorption and Biomass Accumulation in Three Woody Legumes. IITA P.M.B. 5320 Ibadan, Nigeria. BiologicalAgriculture and Horticulture 1996, 13:3, 253-266.

[10]. Kareem, I. A.; Adedeji, T.A and Usman, M.B 2001. Pre-treatment Effects on the Germination and Early Growth of Albizia lebbeck Benth and its Potential as Livestock Feed. The Antenna: Journal of Science and Technology 1 (1): 48-53.

[11]. Kareem, I. A.; Chomini, M.S. and Mohammed, B.I. 2002. Effects of Pre- Germination Treatments and Early Growth Studies on Detarium microcarpum and the Nutrient Status of its Fruits. Journal of Sustainable Tropical Agriculture 3: 51-55.

[12]. Kareem, I. A.; Obiaga, P.C.; Owa, O.; Okonkwo, M.C.; Nwadike, C. and Sani, Y. R. 2005. Propagation of Albizia lebbeck Benth from Cuttings as an Alternative to Production from Seeds. Nigerian Journal of Botany.18:106-110.

[13]. Kareem, I. A. and Akindele, O. (2015). Evaluation of the responses of Solanum melogena to different soil types and levels of NPK fertilizer. Donnish Journal of Agricultural Research (DJAR) Manuscript Number DJAR - 2015 - 1082(6): 048 - 054. (UK).

[14]. Kareem, I. A. and Adegoke, A. O. (2015). Response of Glycine max (soybean)to different soil types and levels of NPK fertilizer. International Journal of Agricultural Research and Review (IJARR) 3(7): 356-358 (Nigeria).

[15]. Kareem, I. A. (2017). Impact of Albizia lebbeck Benth on soil nutrient status and crop yield under agroforestry system (alley cropping). Published Proceedings of the $9^{\text {th }}$ ISTEAMS International Multidisciplinary Conference at the University of Ghana, Legon, Accra, Ghana, $25^{\text {th }}-27^{\text {th }}$ October, 2017, pp. 231-240.

[16]. Lowry, J. B. and Lowry. J. B. C. (1991) Canopy growth of Albizia lebbeck in the semi arid tropics. Nitrogen Fixing Tree Research Reports 9 \& 92.

[17]. Lulandala, L. L. L. and Hall, J. B. (1991).Leucaena leucocephala: Potential Role in Rural Development ICRAF Working Paper No.65 ICRAF House, off the Limuru Road, P. O. Box 30677, Nairobi Kenya.pp.1-6.

[18]. Pokhriyal, T. C; Chaukiyal, S. P. and Singh, K. C. H. (1996) .Nitrogen Fixation and Nodulation Behaviour in Relation to Seasonal Changes in Six Multipurpose Tree Species. Plant Physiology, Botany Division, Forest Research Institute Dehra Dun, India. IndianForester.122:8,718-726.

[19]. Prinsen, J. H. (1986) Potential of Albizia lebbeck as a tropical fodder tree- a review of literature Tropical Grasslands 29. 78-83 Young, A. (1985). Effects of Trees on Soils. Commonwealth Series Council. pp. 28-41. 